\title{
Hepatitis viruses in Ethiopia: a systematic review and meta-analysis
}

\author{
Yeshambel Belyhun ${ }^{1,2^{*}}$, Melanie Maier ${ }^{1}$, Andargachew Mulu ${ }^{1,2}$, Ermias Diro ${ }^{3}$ and Uwe Gerd Liebert ${ }^{1}$
}

\begin{abstract}
Background: The existing seroepidemiological data on viral hepatitis in Ethiopia showed a wide variation in prevalence pattern and the clinical and public health burden have been underestimated. The aim of this systematic review and meta-analysis was to provide a clear and comprehensive estimation of viral hepatitis epidemiology and the potential clinical burdens in Ethiopia.

Methods: A comprehensive literature search was carried out from five decades (1968-2015) published studies from biomedical databases; PubMed, Google scholar, Medline and Web of Science.

Results: The overall pooled prevalence of hepatitis B virus (HBV) was $7.4 \%$ (95\%Cl: 6.5-8.4). The pooled prevalence among subgroups showed 5.2\% (95\%Cl: 3.7-7.4) in human immunodeficiency virus (HIV) infected individuals, 8.0\% (95\%Cl: $5.9-10.7)$ in community based studies, $8.4 \%$ (95\%Cl: $5.4-12.7)$ in blood donors, $11.0 \%$ (95\%Cl: $7.5-15.9)$ in immigrants and 6.9\% (95\%Cl: 5.6-8.5) in other groups. Among study parameters considered during meta-regression analysis, only study years were associated with a decreasing HBV prevalence rate over time. The overall pooled prevalence of anti-hepatitis C virus antibody (anti-HCV) was 3.1\% (95\%Cl: 2.2-4.4). Unlike HBV, the anti-HCV prevalence in HIV infected individuals was higher $(5.5 \%, 95 \% \mathrm{Cl}: 3.8-7.8 \%, p=0.01)$ than the prevalence observed in the other subgroup of study population. Although relatively few data were available, hepatitis virus A (HAV), D (HDV) and $\mathrm{E}$ (HEV) were also circulated in Ethiopia.

Conclusions: This review indicates that all types of viral hepatitis origins are endemic in Ethiopia. Adapting a recommended diagnostic and treatment algorithm of viral hepatitis in the routine healthcare systems and implementing prevention and control policies in the general population needs an urgent attention.
\end{abstract}

Keywords: HBV, HCV, viral hepatitis, Systematic review, Meta-analysis, Ethiopia

\section{Background}

Hepatitis viruses, such as HAV, HBV, HCV, HDV and HEV cause potentially life-threatening inflammation of the liver, which is characterized by acute and chronic forms of liver disease. According to 2013 World Health Organization (WHO) global health impact report of viral hepatitis [1], more than 240 and 150 million populations were affected by chronic liver disease due to HBV and $\mathrm{HCV}$, respectively. Africa has the second largest number of chronic HBV carriers after Asia and is considered as a region of high endemicity [2]. Despite its high

\footnotetext{
*Correspondence: belyhun@gmail.com

1 Institute of Virology, Faculty of Medicine, Leipzig University, Leipzig, Germany

${ }^{2}$ School of Biomedical and Laboratory Sciences, College of Medicine and Health Sciences, University of Gondar, Gondar, Ethiopia

Full list of author information is available at the end of the article
}

prevalence and highly infectious nature, HCV remains under-diagnosed and under-reported in most African countries [1]. Regarding HAV, Africa is known by high prevalence rate and nearly all older children and adults in the region acquired anti-HAV antibody immunity [3]. HEV is also one of the leading causes of major outbreaks of acute viral hepatitis worldwide, especially in developing countries [4]. Similarly, HDV is prevalent worldwide and associated with the most severe form of viral hepatitis [5].

In Ethiopia, an old clinical study showed that liver disease accounted for 12\% hospital admissions and 31\% hospital mortality [6]. Moreover, in Ethiopia and neighbouring Kenya more than $60 \%$ of chronic liver disease and up to $80 \%$ of hepatocellular carcinoma (HCC) are due to chronic HBV and HCV infections [6, 7]. Unlike 
HAV, HDV and HEV, which are not extensively studied, several HBV and HCV seroepidemiological studies were available in the country. However, the majority of the reports showed epidemiological variations of 2.1 to $25.0 \%$ over time and across geographical areas as well as the same localities [8-17]. More importantly, because of HIV pandemic and possible epidemiological overlap as the result of shared transmission ways and risk factors, viral hepatitis-HIV co-infection and subsequent severe forms of clinical complications could be potentially high in the country. Nevertheless, the clinical and public health burdens due to viral hepatitis in general are still given no emphasis in the country's health system. For instance, a recent report showed the presence of very limited knowledge, minimal awareness and underestimation of the viral hepatitis prevalence and disease burden in the country, which have resulted insufficient budgetary and organizational focus [7]. Moreover, according to the WHO report, Ethiopia is regarded as a country with no national strategy for surveillance, prevention and control of viral hepatitis, but the country is classified under the geographical regions with intermediate to hyperendemic viral hepatitis infections [1]. Thus, the lack of a consolidated epidemiological data on the burden of viral hepatitis in Ethiopia might be responsible for the absence of practical action at the policy level. Therefore, this systematic review and meta-analysis was made using data published in the last five decades (1968-2015) to provide a quantified estimate of the problem as a step toward for a better understanding of the viral hepatitis epidemiology, clinical burden and the situation of human immunodeficiency virus (HIV) co-infection in Ethiopia.

\section{Methods}

\section{Search strategy}

A comprehensive literature search was carried out from biomedical databases; PubMed, Google scholar, Medline and Web of Science according to Operations Manual of the Global Burden of Diseases for systematic epidemiological reviews of targeted diseases or condition frequency [18] and Preferred Reporting Items for Systematic Reviews and Meta-analysis (PRISMA) [19]. The search focused on all published studies with epidemiological and/or clinical data on the seroprevalence of hepatitis viruses (HAV, $\mathrm{HBV}, \mathrm{HCV}, \mathrm{HDV}$, and HEV) in Ethiopia from the first scientific description (1968) to 2015. During the search, the following keywords (terms) were used; ["hepatitis A" AND (seroprevalence OR prevalence) AND "Ethiopia"], ["hepatitis B" AND (seroprevalence OR prevalence) AND "Ethiopia"], ["hepatitis C" AND (seroprevalence OR prevalence) AND "Ethiopia"], ["hepatitis D" AND (seroprevalence OR prevalence) AND "Ethiopia"], ["hepatitis E" AND (seroprevalence OR prevalence) AND "Ethiopia"]. The search was repeated by replacing the full written phrases using the abbreviated form of each respective hepatitis virus. Similarly, key terms like "Epidemiology", "Viral liver disease", "Viral hepatitis and HIV coinfections" were used in place of the terms "Seroprevalence" and "Prevalence".

\section{Inclusion and exclusion criteria}

Abstracts were screened to determine the relevance of each study. All studies that reported "seroprevalence" and/or "clinical isolation of viral hepatitis" were selected for inclusion according to PRISMA Flow Diagram [19] (Fig. 1). The inclusion was restricted to original research articles published in English language. The studies also included Ethiopian Jews who immigrated to Israel and screened for hepatitis viruses at the time of their arrival.

\section{Data source}

The screened articles were organized and subgrouped into five major study population types: community based, blood donors, symptomatic liver disease patients, HIV co-infected individuals and various other groups (healthcare workers and medical waste handlers, out and inpatient department patients, street dwellers, pregnant women, diabetic patients, HIV voluntary counselling and testing (VCT) centres clients and commercial sex workers).

\section{Data extraction and quality assessment}

In each abstract and/or full text of the article which was considered to be eligible, information about the study area, year of sample collection and publication, study population, sample size, type of screening kits used and other useful variables were recorded (Additional files 1 and 2). The studies were assessed to identify 'seroprevalence' as an outcome of serological evidence for each of the hepatitis viruses. The quality and eligibility of the screened articles were assessed using a 12 point scoring system based on modified Downs and Black [20] check lists. Special emphases were given for clarity of objective, method, study population characteristics and finding presentations. Articles with low quality score were excluded during the meta-analysis (Additional files 1 and 2).

\section{Data analysis}

The extracted data were systematically restructured among viral origin, study area, study groups and study year during the systematic review. The subgrouped data were analysed using simple descriptive statistics during the systematic review. Accordingly, a median and inter quartile range (IQR) values across each subgroup (community based, blood donors, symptomatic liver disease patients, HIV infected individuals, and various other groups of the society were calculated because of 


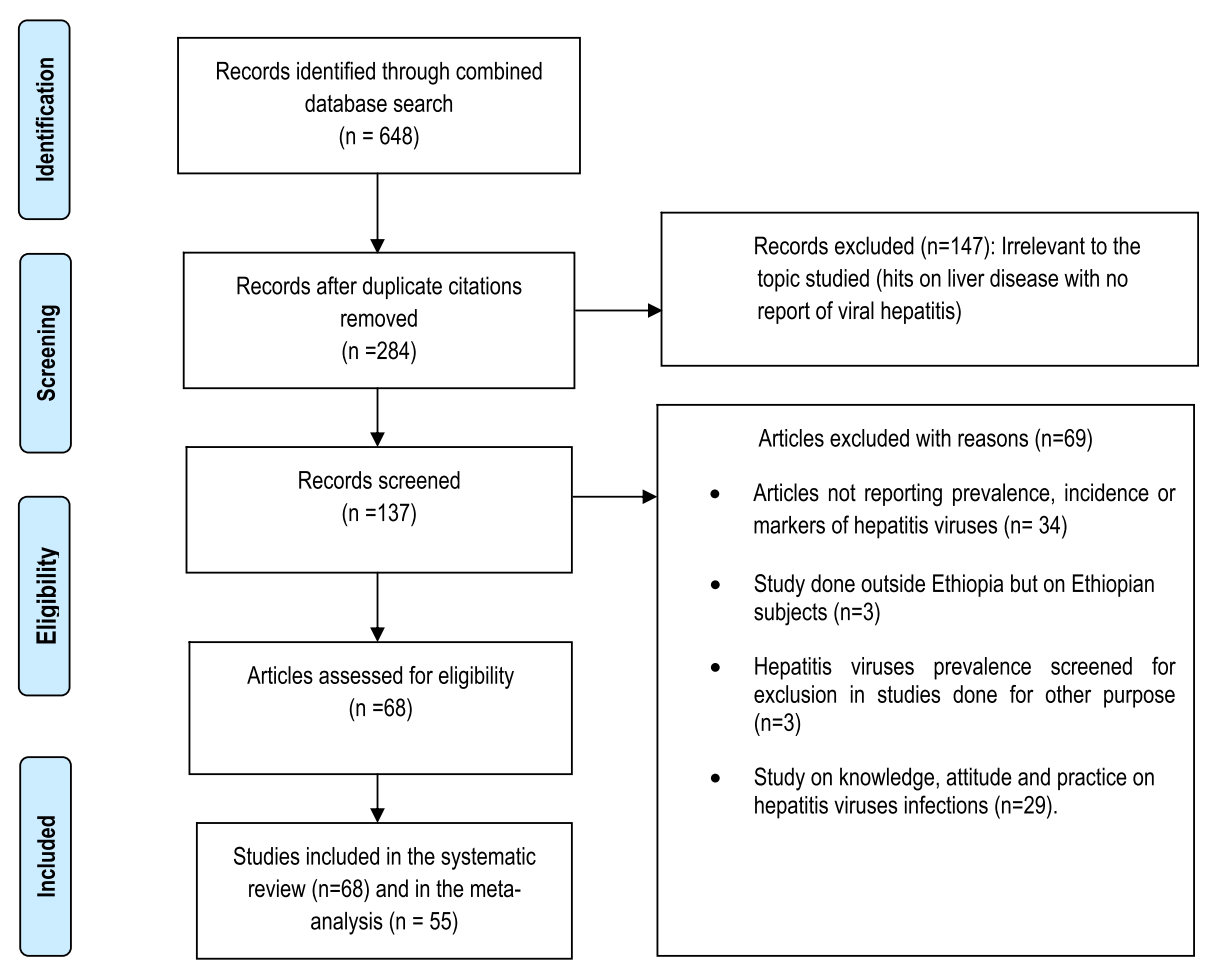

Fig. 1 Flow diagram of studies reviewed, screened and included

expected heterogeneity in terms of the study area, time, sample size and the study design.

During the meta-analysis, all selected studies were combined and a random effects model by DerSimonian and Laird [21] were used to estimate overall pooled prevalence. Since the risks of viral hepatitis exposure are potentially high in symptomatic liver disease patients, the metaanalysis was done independently in order to avoid the potential bias on the outcome of pooled estimation. Cohran's Q (low $P$ value indicates presence of heterogeneity) and and I squared $\left(\mathrm{I}^{2}\right)$ (with $\mathrm{I}^{2}>50 \%$ denoting substantial heterogeneity statistical tests) were conducted to test heterogeneity [22]. The subgroup analysis was performed among the community based studies, blood donors, HIV infected individuals and other groups. The subgroup analysis was not considered for the screening kits used because of the observed homogeneity in the types of the kits (which include an immunoassay based screening kits such as enzyme linked immunoassay, radioimmunoassay and chromatographic immunoassay) (Additional files 1 and 2). Meta-regression analysis was used to determine potential confounders such as mean age groups, study population types, year of study and geographical zones. The mean age group meta-regression was considered for those studies which only reported the mean age (Additional files 1 and 2). The overall fixed and random effects model with $95 \%$ confidence intervals (95\% CIs) were calculated and illustrated using a forest plot graph presentation. The meta- analysis was not considered for data extracted for HAV, HDV and HEV since the number of available studies was very small. Compressive meta-analysis software version 3.3., 2014 (www.meta-analysis.com) was used during the metaanalysis.

\section{Results}

Demographic and study population characteristics

The population of Ethiopia was 22 million at the time (1960s) when the first HBV seroprevalence data were reported. After 30 years, when many of the seroepidemiological and few clinical reports of hepatitis viruses were available, the population steadily increased to 48 million [23]. Currently, with a population of 94 million, the country is the second most populous in Africa. The total study population size screened for hepatitis viruses and involved in this systematic review and meta-analysis were 79,931. Among these, 62,955 were screened for hepatitis viruses from the general population. About 5,229 were from symptomatic patients with acute (867) and chronic (1020) liver diseases, and outpatient department attendants $(3,342)$. The rest 11,747 were from HIV infected individuals. Geographically, the majority of population screened for hepatitis viruses were from central Ethiopia (mainly in Addis Ababa) $(45,037)$, northern Ethiopia $(16,071)$, southern Ethiopia $(17,207)$ and from Ethiopian immigrants to Israel (1616). Overall, 68 studies were eligible for the review and among these, 26 studies reported both HBV and anti- 
HCV seroprevalence and the rest 6 and 36 studies reported only HCV and HBV, respectively. The mean age group of the study population screened for $\mathrm{HBV}$ and $\mathrm{HCV}$ was 28.9 \pm 6.1 (range 14-48) and $28.2 \pm 7.3$ (range 16-55) years old, respectively. The peak prevalence was reported between the group of 24-39 and 20-37 years old, respectively to HBV and HCV (Additional files 1 and 2). All of the selected studies were used immunoassay based kits of various types as their primary screening test. In addition, only four (6.1\%) studies (two each for HBV and HCV) used PCR for measuring viraemia level (Additional files 1 and 2).

\section{Epidemiology of HBV}

The first documented HBsAg prevalence rate was $3.9 \%$ in 1968 [24]. Then later the magnitude of the peak HBsAg prevalence (10.8\%) was available in 1986 and 1989 [25, 26] and then decreased to $6.2 \%$ in 2003 [27] and 5.3\% in 2007 [28] from the community based studies (Fig. 2a). However, studies conducted in blood donors (Fig. 2b) reported a slightly higher median prevalence of $8.7 \%$ (IQR $=4.6-16.9$ ) than the $6.2 \%$ median (IQR $=5.6-9.9$ ) prevalence rate in the community based studies (Fig. 2a). Moreover, the reports from the blood donors of the same localities like in Bahir Dar (25 vs. $4.11 \%)$ [8, 13], Jimma $(24.2$ vs. $2.1 \%)[14,15]$ and Gondar (14.4 vs. 4.7\%) [16, 17] showed marked epidemiological discrepancies over time (Fig. 2b). The HBsAg was also reported among various segments of the society such as healthcare professionals $(7.3-9.0 \%)[29,30]$, medical waste handlers (6.0-6.3\%) [31, 32], outpatient and inpatient department attendants $(4.7-7.4 \%)[33,34]$, street dwellers (10.9\%) [35], pregnant women (3.0-7.3\%) [36-40], diabetic patients (3.7\%) [41], HIV VCT centres clients $(5.7 \%)[10,42]$ and commercial sex workers $(6.0 \%)$ [43] (Fig. 2c). The HBsAg prevalence among Ethiopians Jews who immigrated to Israel in different times also showed 6.2 to $19 \%$ prevalence rate $(11.5 \%$ median; IQR 7.6-16.6) (Fig. 2d). Overall, the median HBsAg prevalence in the general population (Fig. 2a-d) showed 6.3\% (IQR $=5.2-10.8)$ over the last five decades.

Fourty two $(67.7 \%)$ out of the 62 studies which reported HBsAg prevalence (Additional file 1) were used in the meta-analysis among the general population. The Cohran's $\mathrm{Q}$ and $\mathrm{I}^{2}$ statistic for HBsAg was 509.7 and $91.9 \%$ $(p<0.001)$, respectively which showed the studies were heterogeneous. The overall pooled prevalence of HBV was 7.4\% (95\%CI: 6.5-8.4) (Fig. 3). The subgroup meta-analysis of study parameters such as the mean age group, study population types, year of study and geographical zones showed significant variations in the HBV prevalence (Table 1). In particular, the pooled prevalence among
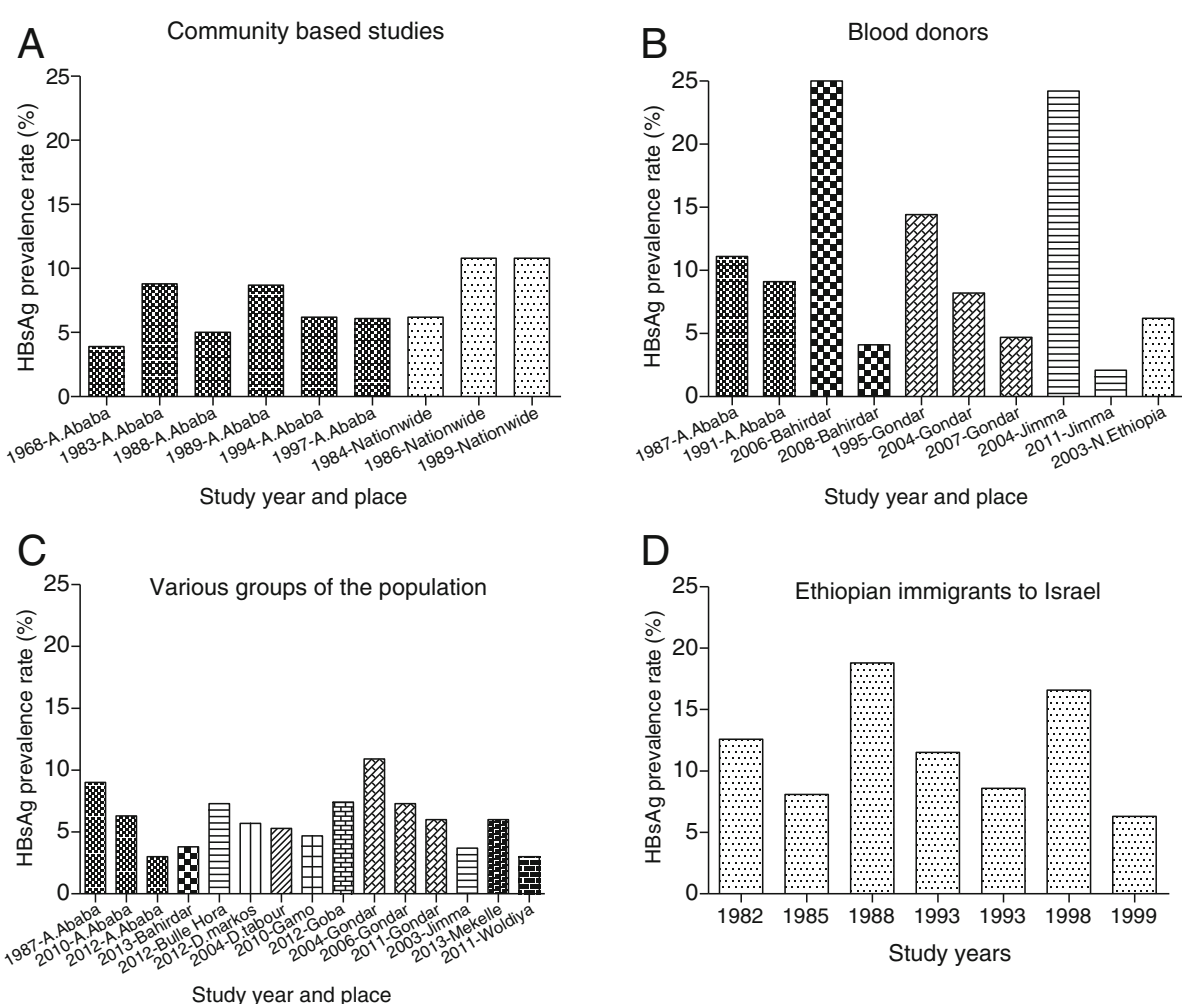

Fig. 2 HBsAg prevalence among the community based studies (a) [24-26, 52, 59, 76, 85, 87, 88], blood donors (b) [8, 9, 13-17, 57, 89, 90], various groups of the society (healthcare workers, outpatient department attendants, medical waste handlers, pregnant women, HIV voluntary counseling and testing (VCT) clients, commercial sex workers) (c) [10, 29-41] and Ethiopian Jews immigrants to Israel (d) [54, 91-96] 


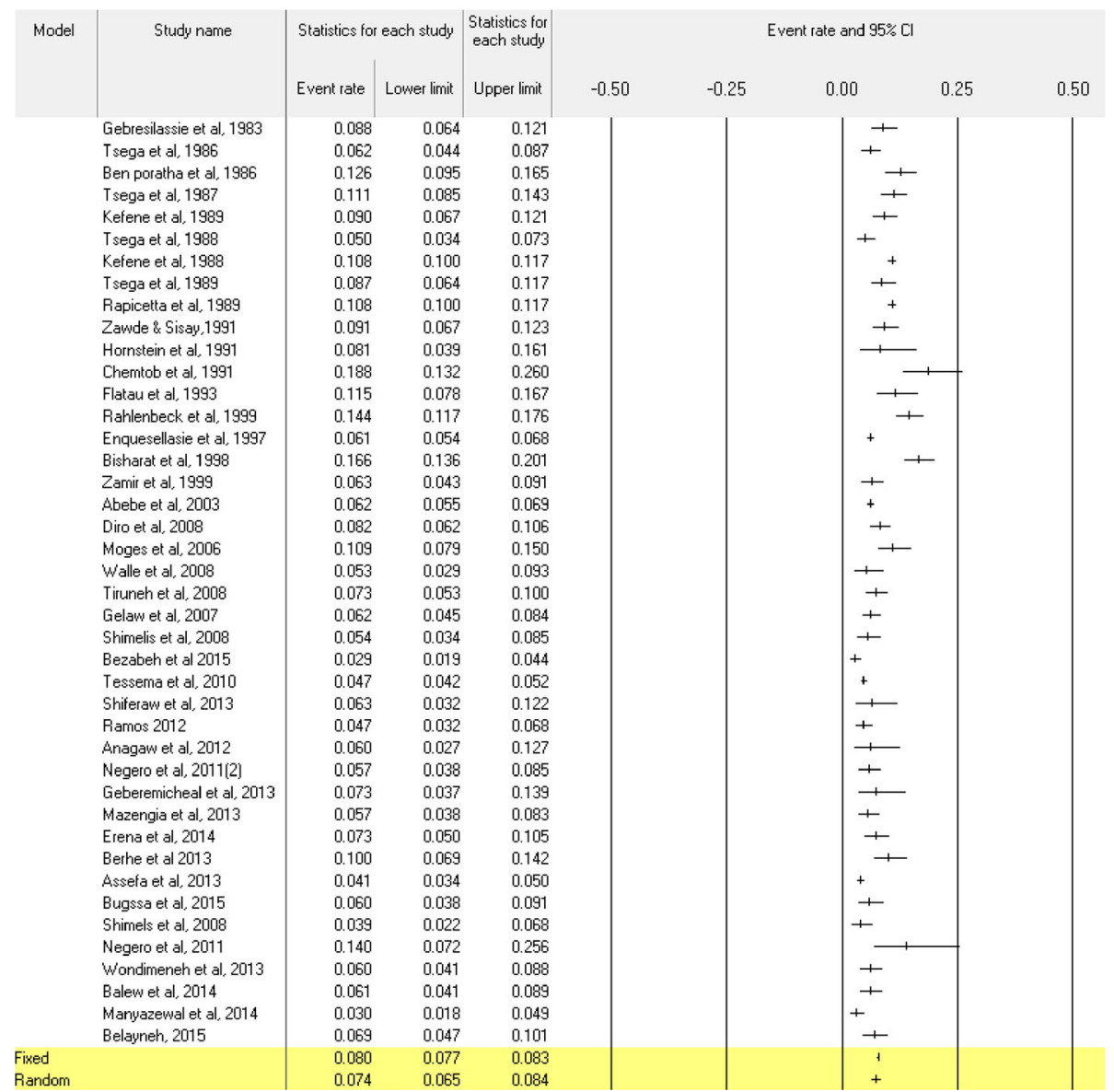

Fig. 3 The meta-analysis and forest plot presentation of the HBsAg seroprevalence from 1983 to 2015. (Citations of studies used in the analysis from top to bottom: $[85,59,91,89,29,87,25,87,26,90,92,93,54,16,88,95,96,27,9,35,38,39,57,42,97,17,31,33,32,62,30,10,34,63,13,43,42,62,64,67,53,65])$

subgroup was $5.2 \%$ (95\%CI: $3.7-7.4)$ in HIV infected individuals, $8.0 \%$ (95\% CI: 5.9-10.7) in community based studies, $8.4 \%$ (95\% CI: 5.4-12.7) in blood donors, $11.0 \%$ (95\%CI: $7.5-15.9)$ in immigrants and 6.9\% (95\%CI: 5.6-8.5) in other groups. Among the above study parameters considered during meta-regression analysis, only study years were associated with a decreasing HBV prevalence over time (Additional file 3). The meta-regression plots for the mean age group and study years were presented in Additional file 4. Similarly, many studies in symptomatic liver disease patients reported $\mathrm{HBsAg}$ detection ranging from 9.9 to $35.8 \%$ [44-51] with a median prevalence of $21.2 \%$ (IQR $=13.4-$ 33.6) (Table 2). The meta-analysis estimate among these patients also showed 20.0\% (95\%CI: 15.0-26.1) (Additional file 5).

In some studies, along with HBsAg other HBV markers; anti-hepatitis B surface antigen (anti-HBs), anti-hepatitis B core antigen (anti-HBcAg) and hepatitis e $\mathrm{Ag}(\mathrm{HBeAg})$ and anti-hepatitis e antigen (anti-HBeAg) were also determined (Table 3). The peak prevalence rate $(82 \%)$ for any markers was reported among chronic liver disease patients, whereas the lowest rate (42.2\%) was in the general population [52]. The anti-HBs antibody was recorded at $11.6 \%$ in HIV infected individuals [53] and the highest rate (73.6\%) was among healthcare workers [25]. Similarly, the $\mathrm{HBeAg}$ prevalence rate ranges from 0.6 to $44.0 \%$ (Table 3 ).

\section{Epidemiology of HCV}

Except a 3\% prevalence rate of the time for Ethiopian immigrants to Israel in 1991 [54], the seroepidemiological survey of $\mathrm{HCV}$ in a community based studies showed 0.8 to $2 \%$ prevalence rate before the year $2000[55,56]$. Over the years 2000s, relatively lower and comparable prevalence rates were documented from blood donors in north Ethiopia (1.7\%) in 2007 [57], Gondar (0.7\%) in 2010 [17], Jimma (0.2\%) [16] and Bahir Dar (0.6\%) in 2011 [13] (Table 4). In contrast, unusually high $\mathrm{HCV}$ prevalence was reported in blood donors from Gondar (5.8\%) in 2008 [9] and from Bahir Dar (13.3\%) in 2007 [8]. A similar variation was also reported, among other groups, such as VCT clients [10-12], diabetic patients [58], antenatal care (ANC) [39] 
Table 1 Subgroup meta-analysis of HBV and HCV prevalence estimation in Ethiopia

\begin{tabular}{|c|c|c|c|c|c|c|}
\hline & Study parameters & Subgroup & Studies included & Prevalence $\%(95 \% \mathrm{Cl})$ & $1^{2} \%$ & $P$-value \\
\hline \multirow[t]{14}{*}{ HBV } & \multirow[t]{5}{*}{ Study population } & Community based & 7 & $8.0(5.9-10.7)$ & 96.1 & $<0.001$ \\
\hline & & Blood donors & 6 & $8.4(5.4-12.7)$ & 95.4 & $<0.001$ \\
\hline & & HIV co-infected & 7 & $5.2(3.7-7.4)$ & 75.9 & $<0.001$ \\
\hline & & Immigrants to Israel & 5 & $11.0(7.5-15.9)$ & 79.0 & 0.001 \\
\hline & & Other groups ${ }^{a}$ & 17 & $6.9(5.6-8.5)$ & 87.3 & $<0.001$ \\
\hline & \multirow[t]{2}{*}{ Mean age group ${ }^{b}$} & $14-29$ & 8 & $7.1(5.6-8.9)$ & 85.3 & $<0.001$ \\
\hline & & $30-45$ & 9 & $6.7(5.6-8.1)$ & 39.6 & $<0.001$ \\
\hline & \multirow[t]{4}{*}{ Study year } & 1980-1989 & 9 & $9.4(8.2-10.7)$ & 74.5 & $<0.001$ \\
\hline & & 1990-1999 & 8 & 10.7(7.3-15.4) & 94.3 & $<0.001$ \\
\hline & & 2000-2009 & 9 & $6.3(5.1-7.9)$ & 76.6 & $<0.001$ \\
\hline & & 2010-2015 & 16 & $5.7(4.9-6.6)$ & 63.4 & $<0.001$ \\
\hline & \multirow[t]{3}{*}{ Geographical zone } & Central Ethiopia & 13 & $6.4(5.3-7.6)$ & 81.3 & $<0.001$ \\
\hline & & Northwest Ethiopia & 17 & $8.2(6.2-10.8)$ & 93.7 & $<0.001$ \\
\hline & & Other regions ${ }^{c}$ & 12 & $7.7(6.5-9.1)$ & 82.6 & $<0.001$ \\
\hline \multirow[t]{10}{*}{$\mathrm{HCV}$} & \multirow[t]{2}{*}{ Study population } & General population $^{d}$ & 16 & $2.4(1.6-3.6)$ & 90.4 & $<0.001$ \\
\hline & & HIV co-infected & 8 & $5.5(3.8-7.8)$ & 81.8 & $<0.001$ \\
\hline & \multirow[t]{2}{*}{ Mean age group } & $19-29$ & 6 & $2.3(0.9-5.8)$ & 96.6 & $<0.001$ \\
\hline & & $30-39$ & 9 & $3.7(2.4-5.8)$ & 84.4 & $<0.001$ \\
\hline & \multirow[t]{3}{*}{ Study year } & 1990-1999 & 3 & $2.0(1.5-2.7)$ & 0.00 & $<0.001$ \\
\hline & & $2000-2009$ & 6 & $2.9(1.4-5.9)$ & 94.2 & $<0.001$ \\
\hline & & 2010-2015 & 15 & $3.7(2.5-5.4)$ & 88.2 & $<0.001$ \\
\hline & \multirow[t]{3}{*}{ Geographical zone } & Central Ethiopia & 6 & $3.5(2.0-6.0)$ & 89.0 & $<0.001$ \\
\hline & & Northwest Ethiopia & 10 & $2.8(1.6-4.7)$ & 87.8 & $<0.001$ \\
\hline & & Other regions ${ }^{\mathrm{e}}$ & 8 & $3.4(1.7-6.5)$ & 94.8 & $<0.001$ \\
\hline
\end{tabular}

${ }^{a}$ Other groups include: healthcare workers and medical waste handlers, out and inpatient department patients, street dwellers, pregnant women, diabetic patients, HIV voluntary counseling and testing (VCT) centers clients and commercial sex workers. ${ }^{\mathrm{b}}$ It considered for those studies which only reported mean age 'Includes: Nationwide studies $(n=3)$, North $(n=1)$, North east $(n=2)$, South east $(n=5)$ and South west $(n=1)$. ${ }^{\mathrm{I}}$ It includes: Community based studies, blood donors, HIV co-infected and immigrants. " one, three, one, and three studies were from nationwide, north, northeast and southwest Ethiopia, respectively

and medical waste handlers [32] (Table 4). Likewise, the magnitude of anti-HCV antibody from chronic liver disease patients showed a variable prevalence rate over time with high (37.8\%) in 1995 [49] and low (2.7\%) in 2014 [51] (Table 4). For the HCV meta-analysis, 24 (75.0\%) studies were eligible and selected from the total of 32 studies (Additional file 2). The Cohran's Q (283.1) and $\mathrm{I}^{2}$ statistics $(91.9 \%, p<0.001)$ showed heterogeneity among studies. The pooled prevalence rate of anti-HCV antibody was 3.1\% (95\%CI: 2.2-4.4) (Fig. 4). The subgroup meta-analysis showed significant variations in the HCV prevalence among the study parameters (Table 1 ).

\section{Epidemiology of HAV, HDV and HEV}

An early report of HAV antibody prevalence rates was 84 and $50 \%[46,59]$, respectively among the general population and children. In regard to HDV, available scientific reports in the 1980s showed from 5.8 to $9.6 \%$ of anti-HDV antibody prevalence rates among the general population [59, 60].
HEV was also reported 59\% in acute pregnant women [61] and $93 \%$ in acute patients and 3\% in healthy controls [47].

\section{Epidemiology of viral hepatitis among HIV infected individuals}

Cases-control studies of HBsAg among HIV infected individuals showed a record of $14 \%$ (vs. $4.3 \%$ in the control) in Shashemene (Southern Ethiopia) [62] and 5.4\% (vs. 3.9\% in the controls) from the central Ethiopia in Addis Ababa [42]. Studies which included HIV infected individuals alone reported $2.3 \% \mathrm{HBsAg}$ prevalence rate in Woldiya [63] and 5.6\% in Gondar [64] and 6.9\% in Hawassa [65] from the north, northwest and south part of Ethiopia, respectively. Overall, for the last 10 years, the median HBsAg seroprevalence among HIV infected individuals was $6.0 \%(\mathrm{IQR}=3.0-6.0)$ with an increased trend prevalence $\left(X^{2}=15.1, p<0.001\right)$ when compared to HIV negative controls. In the subgroup meta-analysis, HBV prevalence in HIV co-infected individuals was 5.2\% $(95 \%$ CI 3.7-7.4, $p<0.001)$ (Table 1). 
Table 2 HBsAg prevalence of acute and chronic liver disease patients in different regions of Ethiopia from 1984 to 2013

\begin{tabular}{|c|c|c|c|c|c|c|}
\hline $\begin{array}{l}\text { Sampling } \\
\text { year }\end{array}$ & Study area & Study design & $\begin{array}{l}\text { Study } \\
\text { Population }\end{array}$ & $\begin{array}{l}\text { HBsAg, } n \\
(\%)\end{array}$ & Patients' characterization and evaluation system ${ }^{a}$ & References \\
\hline 1984 & A.Ababa & Prospective longitudinal & 304 & 30(9.9) & $\begin{array}{l}\text { Patients with acute or chronic hepatitis, some with } \\
\text { malignant liver disease, mainly hepatocellular } \\
\text { carcinoma (HCC) }\end{array}$ & [45] \\
\hline 1989 & A.Ababa & Consecutive hospital patients & 334 & $91(27.2)$ & $\begin{array}{l}\text { Based on clinical and histological diagnostic criteria; } \\
\text { patients with chronic hepatitis }(n=114) \text {, cirrhosis } \\
(n=208) \text { and hepatocellular carcinoma }(n=112)\end{array}$ & [46] \\
\hline 1991 & $\begin{array}{l}\text { North } \\
\text { Ethiopia }\end{array}$ & Epidemic outbreak & 423 & $54(12.8)$ & Icteric patients hospitalized during HEV & [47] \\
\hline 1992 & A.Ababa & Consecutive hospital patients & 110 & $22(20.0)$ & $\begin{array}{l}\text { Consecutive acute hepatitis patients and } 19 \\
\text { pregnant women who had HEV infection }\end{array}$ & [48] \\
\hline 1995 & A.Ababa & Consecutive hospital patients & 238 & $65(27.3)$ & $\begin{array}{l}\text { Patients with chronic hepatitis }(n=14) \text {, cirrhotic } \\
(n=156) \text { and HCC }(n=68)\end{array}$ & [49] \\
\hline 2011 & A.Ababa & $\begin{array}{l}\text { Prospective consecutive } \\
\text { hospital patients }\end{array}$ & 120 & $43(35.8)$ & $\begin{array}{l}\text { Patients with chronic liver disease based on clinical } \\
\text { history, ultrasound, and impaired liver function tests. }\end{array}$ & {$[44]$} \\
\hline 2011 & Gondar & Retrospective & 2684 & $386(14.4)$ & $\begin{array}{l}\text { Five year retrospective study on clinically suspected } \\
\text { hepatitis patients from different wards of Gondar } \\
\text { hospital }\end{array}$ & {$[50]$} \\
\hline 2013 & Bale Robe & Retrospective & 358 & $80(22.3)$ & All patients with chronic hepatitis & {$[51]$} \\
\hline
\end{tabular}

${ }^{a}$ The clinical diagnostic criteria for grouping patients as chronic liver disease patients were based on the presence of patient history of either clinical signs like ascites, hepatomegaly, and splenomegaly with other clinical features including jaundice, palmar erythema, clubbing, edema, axillary and pubic hair loss, Spider nevi, flapping tremors, drowsiness, confusion and coma. Ultrasound showing coarse hepatic texture, changes in liver size, increased portal vein diameter, and splenomegaly. Impaired liver function tests, including raised level of alanine aminotransferase (ALT)

The prevalence rate of HCV antibody in HIV infected individuals was $4.5 \%$, which was higher than HIV negative controls (0.8\%) in Addis Ababa [55]. A study from southern Ethiopia in Hawassa [11] showed a $10.5 \%$ prevalence of $\mathrm{HCV}$ in HIV infected individuals compared to $6.0 \%$ in the HIV negative control group. In this report and another similar study in Addis Ababa [65], HCV viraemia was reported 9.1 and $25.4 \%$, respectively from anti-HCV antibody positive individuals. Overall, the $\mathrm{HCV}$ prevalence showed an increasing trend prevalence $\left(X^{2}=18.7, p<0.001\right)$ in HIV infected individuals than noninfected counterparts with a median prevalence of $6.5 \%$ (IQR = 4.2-9.9) [11, 12, 53, 55, 64, 66-69]. In the subgroup meta-analysis, the prevalence of anti-HCV antibody in HIV co-infected individuals was 5.5\% (95\% CI 3.8-7.8, $p<0.001$ ), respectively (Table 1 and Additional file 4). Unlike mean

Table 3 Magnitude of HBV markers among different study populations in different regions of Ethiopia from 1983 to 2011

\begin{tabular}{|c|c|c|c|c|c|c|c|c|c|}
\hline \multirow[b]{2}{*}{$\begin{array}{l}\text { Sampling } \\
\text { year }\end{array}$} & \multirow[b]{2}{*}{ Study area } & \multirow[b]{2}{*}{ Study groups } & \multirow[b]{2}{*}{$\begin{array}{l}\text { Sampled } \\
\text { population }\end{array}$} & \multirow[b]{2}{*}{ HBsAg n (\%) } & \multicolumn{4}{|c|}{ Other HBV markers } & \multirow[t]{2}{*}{ References } \\
\hline & & & & & $\begin{array}{l}\text { anti-HBs, } \\
\mathrm{n}(\%)\end{array}$ & $\begin{array}{l}\text { anti-HBCAg, } \\
\mathrm{n}(\%)\end{array}$ & $\begin{array}{l}\text { anti-HBeAg, } \\
\text { n (\%) }\end{array}$ & $\begin{array}{l}\text { HBeAg, } \\
\text { n (\%) }\end{array}$ & \\
\hline 1983 & Nationwide & $\begin{array}{l}\text { Gen. population, } \\
\text { children \& ANC } \\
\text { attendants }\end{array}$ & 396 & $36(9.1)$ & $221(67.2)^{a}$ & - & $19(55.9)^{d}$ & $15(44.0)^{9}$ & [85] \\
\hline 1984 & Nationwide & General population & 500 & $31(6.2)$ & $152(30.4)$ & $16(3.2)$ & $10(32.3)^{\mathrm{e}}$ & $8(25.8)^{e}$ & [52] \\
\hline 1987 & A. Ababa & Health workers & 432 & $39(9.02)$ & $200(46.3)$ & $316(73.1)$ & - & - & [29] \\
\hline 1989 & Nationwide & General population & 5265 & $569(10.8)$ & $61.4^{\mathrm{b}}$ & $132(2.5)$ & $298(57.1)^{f}$ & $99(19.0)^{f}$ & [26] \\
\hline 1994 & A.Ababa & General population & 4736 & $292(6.2)$ & $1796(40.7)^{c}$ & 1734 (36.6) & - & $71 / 279(25.4)$ & [27] \\
\hline 1995 & A.Ababa & $\begin{array}{l}\text { Chronic liver disease } \\
\text { patients }\end{array}$ & 238 & $65(27.0)$ & $131(55.0)$ & - & - & - & [49] \\
\hline 1998 & Immigrants to Israel & Familial members & 506 & $84(16.6 \%)$ & - & - & - & 17/84(20.2) & [95] \\
\hline 2007 & A. Ababa & $\begin{array}{l}\text { HIV patients \& VCT } \\
\text { clients }\end{array}$ & 620 & $29(4.7)$ & - & $277(44.7)$ & - & 3/29(10.3) & [42] \\
\hline 2010 & Gamo HP & $\begin{array}{l}\text { Inpatients department } \\
\text { clients }\end{array}$ & 556 & $26(4.7)$ & - & $7(1.4)$ & - & - & [33] \\
\hline 2011 & A.Ababa & HIV patients & 500 & 15(3.0) & $58(11.6)$ & - & - & $3(0.6)$ & [53] \\
\hline
\end{tabular}

${ }^{a}$ ANC-Antenatal Care. ${ }^{b}$ Only the percentage was presented from the origional study. $\mathrm{HBeAg}$ and anti-HBeAg percentages were calculated on the basis of sample size of $\mathrm{HBsAg}$ positive individuals; ${ }^{\mathrm{e}}=31,{ }^{\mathrm{d}}=34,{ }^{\mathrm{f}}=522$ and ${ }^{\mathrm{g}}=19 .^{\mathrm{a}}=329$ and $^{\mathrm{c}}=4414$ among HBsAg negatives 
Table 4 Magnitude of HCV antibody prevalence among different study population in different regions of Ethiopia from 1988 to 2014

\begin{tabular}{|c|c|c|c|c|c|}
\hline Study group & Sampling year & Study area & Study population & Anti-HCV Ab frequency (\%) & References \\
\hline \multirow[t]{3}{*}{ Community based } & 1993 & A.Ababa \& its outskirts & 1580 & $32(2.0)$ & [56] \\
\hline & 1994 & A.Ababa & 2663 & $29(0.8)$ & [55] \\
\hline & 2002 & Kemissie \& Omo & 5248 & $68(1.3)$ & [28] \\
\hline \multirow[t]{7}{*}{ Blood donors } & 1995 & A.Ababa & 500 & $7(1.4)$ & [49] \\
\hline & 2003 & North Ethiopia & 600 & $10(1.7)$ & [57] \\
\hline & 2004 & Gondar & 600 & $35(5.8)$ & [9] \\
\hline & 2006 & Bahirdar & 324 & $43(13.3)$ & [8] \\
\hline & 2007 & Gondar & 6361 & $35(0.7)$ & [17] \\
\hline & 2008 & Bahir Dar & 2384 & $15(0.6)$ & [13] \\
\hline & 2010 & Jimma & 6063 & $12(0.2)$ & [15] \\
\hline \multirow[t]{6}{*}{ Symptomatic liver disease patients } & 1988 & North Ethiopia & 139 & $20(14.0)$ & [47] \\
\hline & 1992 & A.Ababa & 110 & $21(19.0)$ & [48] \\
\hline & 1995 & A.Ababa & 238 & $90(37.8)$ & [49] \\
\hline & 2011 & A. Ababa & 120 & $27(22.5)$ & [44] \\
\hline & 2011 & Gondar & 2684 & $322(12.0)$ & [50] \\
\hline & 2013 & Bale Robe & 220 & $6(2.7)$ & [51] \\
\hline \multirow[t]{10}{*}{ HIV infected individuals } & 1994 & A. Ababa & 165 & $8(4.8)$ & [55] \\
\hline & 2006 & A. Ababa & 734 & $50(6.8)$ & [66] \\
\hline & 2008 & Hawassa & 400 & $42(10.5)$ & [11] \\
\hline & 2011 & A. Ababa & 500 & $18(3.6)$ & [53] \\
\hline & 2011 & Mekele & 174 & $16(9.2)$ & [12] \\
\hline & 2012 & D/ Tabour & 395 & $5(1.3)$ & [67] \\
\hline & 2013 & A.Ababa & 387 & $25(6.5)$ & [68] \\
\hline & 2013 & Gondar & 400 & $22(5.5)$ & [64] \\
\hline & 2013 & Bahirdar & 269 & $59(21.9)^{a}$ & [100] \\
\hline & 2014 & Bahirdar & 253 & $14(5.5)$ & [69] \\
\hline \multirow[t]{9}{*}{ Others ${ }^{b}$} & 2006 & Gondar & 480 & $6(1.3)$ & [39] \\
\hline & 2006 & A. Ababa & 1220 & $21(1.7)$ & [66] \\
\hline & 2008 & Hawassa & 400 & $24(6.0)$ & [11] \\
\hline & 2010 & Jimma & 304 & $30(9.9)$ & [58] \\
\hline & 2010 & Jimma & 300 & $10(3.3)$ & [58] \\
\hline & 2010 & Gamo HP & 556 & $1(0.2)$ & [33] \\
\hline & 2011 & Gondar & 200 & $2(1.0)$ & [32] \\
\hline & 2011 & Mekele & 126 & $2(1.6)$ & [12] \\
\hline & 2012 & D/ Markos & 423 & $6(1.4)$ & [10] \\
\hline
\end{tabular}

a Reported as $18.9 \%$ in the original work, but the $3.0 \%$ anti-HCV antibody reported as co-infected with $\mathrm{HBsAg}$ was summed up and became $21.9 \%$

b Includes antenatal care attendants, HIV voluntary counselling and testing (VCT) clients (HIV negative), VCT clients, diabetic patients, non-diabetic patients (controls for diabetic patients), out and inpatient department clients, healthcare workers and medical waste handlers, and VCT clients

age, study year and geographical zones, the meta-regression analysis showed that HIV co-infection was associated with higher $\mathrm{HCV}$ prevalence rate (Additional files 3 and 4).

\section{Discussion}

This is the first detailed systematic review and metaanalysis study of viral hepatitis in Ethiopia over a large period of time. The findings clearly show the burden of viral hepatitis in the country in general and endemicity of HBV in particular. The findings were also consistent with the estimate of $5-20 \%$ of most African countries [70] and the WHO HBV endemic definition (5-7\% HBsAg prevalence) in the general population of a defined geographical area [1]. Similarly, HBV markers other than HBsAg ever reported in the country have 


\begin{tabular}{|c|c|c|c|c|c|c|c|c|c|}
\hline \multirow[t]{2}{*}{ Madel } & \multirow[t]{2}{*}{ Study name } & \multicolumn{3}{|c|}{ Statistics for each study } & \multicolumn{5}{|c|}{ Event rate and $95 \% \mathrm{Cl}$} \\
\hline & & Event rate & Lower limit & Upper limit & -0.50 & -0.25 & 0.00 & 0.25 & 0.50 \\
\hline & Formmel et al 1993 & 0.020 & 0.014 & 0.028 & & & t & & \\
\hline & Flatau et al 1993 & 0.030 & 0.014 & 0.065 & & & + & & \\
\hline & Tsega et al 1995 & 0.014 & 0.007 & 0.029 & & & + & & \\
\hline & Ayele W' et al 2002 & 0.048 & 0.024 & 0.094 & & & + & & \\
\hline & Gelaw et al, 2007 & 0.017 & 0.009 & 0.031 & & & + & & \\
\hline & Berhe et al 2007 & 0.013 & 0.010 & 0.076 & & & & & \\
\hline & Diro et al, 2008 & 0.058 & 0.042 & 0.080 & & & + & & \\
\hline & Tiruneh et al 2008 & 0.013 & 0.006 & 0.028 & & & + & & \\
\hline & Taye \& Lakew 2013 & 0.065 & 0.044 & 0.094 & & & + & & \\
\hline & Ali et al 2012 & 0.099 & 0.070 & 0.138 & & & + & & \\
\hline & Ali et al 2012 (2) & 0.033 & 0.018 & 0.061 & & & + & & \\
\hline & Alemayehu et al , 2011 & 0.060 & 0.041 & 0.088 & & & + & & \\
\hline & Abreha et al, 2011 & 0.017 & 0.011 & 0.026 & & & $t_{t}$ & & \\
\hline & Hadush et al, 2011 & 0.016 & 0.004 & 0.061 & & & + & & \\
\hline & Abreha et al, 2011 (2) & 0.068 & 0.052 & 0.089 & & & + & & \\
\hline & Alemagheuet al , 2011 & 0.105 & 0.079 & 0.139 & & & + & & \\
\hline & Hadush et al, 2011 & 0.092 & 0.057 & 0.145 & & & + & & \\
\hline & Manyazewal et al. & 0.028 & 0.017 & 0.047 & & & + & & \\
\hline & Wondimeneh et al. & 0.055 & 0.036 & 0.082 & & & + & & \\
\hline & Mazengia et al, 2013 & 0.014 & 0.006 & 0.031 & & & 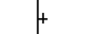 & & \\
\hline & Belew et al 2014 & 0.013 & 0.005 & 0.030 & & & + & & \\
\hline & Anagaw et al 2012 & 0.010 & 0.003 & 0.039 & & & + & & \\
\hline & Molla et al, 2015 & 0.003 & 0.000 & 0.018 & & & & & \\
\hline & Birku et al, 2015 & 0.042 & 0.026 & 0.067 & & & + & & \\
\hline Fined & & 0.038 & 0.035 & 0.042 & & & 1 & & \\
\hline Gandom & & 0.031 & 0.022 & 0.044 & & & & & \\
\hline
\end{tabular}

Fig. 4 The meta-analysis and forest plot presentation of anti-HCV seroprevalence from 1993 to 2015. (Citations of studies used in the analysis from top to bottom: $[56,54,49,55,57,28,9,39,68,58,58,11,66,12,66,11,12,53,64,10,67,32,98,99])$

been in agreement with data from most African countries and support the endemicity of HBV estimated from the HBsAg prevalence.

HBV seroprevalence studies in blood donors were merely geographical representative, which covered north, northwest, southwest and central parts of Ethiopia. However, the HBsAg prevalence in this group was a bit higher $(8.4 \%)$ than the community based studies $(8.0 \%)$, but in agreement with reports on blood donors of other African countries [70-72]. Nevertheless, in Ethiopia, studies in this group showed a marked variation even in the same locality with exceptionally highest $[8,14]$ or lowest $[13,15]$ prevalence rates over time. Apart from geographical location and study time differences, the discrepancies in this group in particular and other groups in general could be due to methodological drawbacks such as small sample size seen from southwest Ethiopia [14] and ill-defined study design from northwest Ethiopia [50]. For instance, the latter study failed to exclude patients who were screened HBsAg for differential diagnosis of other illness, but rather reported 14.4\% HBsAg prevalence by considering the subject as 'clinically suspected viral hepatitis patients'. The other source of the discrepancy might be due to the potential variability in sensitivity and specificity of the commercially available test kits used in each study, although the studies used in this review were based on an immunoassay based screening kits with more or less similar principle of antibody detection.
From early 1980 s to the present time, more than 120,000 [73] Ethiopian Jews immigrated to Israel. Because of the low standards of socio-economic and healthcare status of these migrants, they attracted the focus of public health intervention and were screened for infectious disease agents including hepatitis viruses $[74,75]$. The $11.0 \%$ HBsAg prevalence rate observed were higher than the blood donors, the general population and other groups. This could be due to the fact that the immigrates were originally from rural Ethiopians communities where risky traditional unsafe practices (tattooing, ear piercing, tonsillectomy, circumcision, ritual scars, traditional surgery, unsterilised shaving at the barber shop, dental extraction at home, home delivery by traditional birth attendants, unsafe abortion practices) are commonly practiced. The finding in this group, however, could represent and reflect HBV prevalence in the rural settings of Ethiopia since the majority of the studies concentrated in urban settings. Moreover, the prevalence observed in these immigrants also could indirectly reflect the potential distribution dynamics of hepatitis viruses to the less endemic parts of the world.

In Ethiopia, reports on HBsAg prevalence were also common from groups such as pregnant women, diabetic patients, street dwellers, HIV VCT clients and commercial sex workers. The HBsAg prevalence was hyperendemic among healthcare professionals [29] and medical waste handlers [30] in particular might be associated with occupational risk exposures since they deal with all 
sorts of the infected samples with no HBV vaccination, which is the simplest protection and standard practice elsewhere. A recent study showed that although knowledge about availability of $\mathrm{HBV}$ vaccine was $62 \%$ among healthcare workers, fully vaccinated professionals were only 5.4\% [76]. Another study conducted on Ethiopian surgeons showed that most of them were not vaccinated because of negligence and lack of knowledge about the recent introduction of the vaccine, despite their strong belief HBV vaccine is useful [77]. This could explain the reason that the relatively higher prevalence rate of HBsAg and anti-HBS antibody level among healthcare workers in Ethiopia since the exposure and subsequent natural immune development could be expected relatively higher in this group. As the result, to minimize at least an occupational exposure of HBV infection for such risky groups, an urgent need for the HBV vaccination scheme, awareness creation and attitudinal health education on the universal precaution and safety of blood born infection transmissions are crucial in Ethiopia.

The disease burden caused by HBV and other forms of hepatitis is undocumented in Ethiopia, although acute viral hepatitis, chronic hepatitis, cirrhosis of the liver and HCC accounted for significant hospital admissions and mortality rate [78]. In late 1990s, the most common tumour in medical units in Ethiopia was associated with a $50 \%$ carrier rate of $\mathrm{HBsAg}[7,78]$. In line to this, the overall HBsAg prevalence in the symptomatic liver disease patients estimated 20.0 and $21.2 \%$ from the metaanalysis and systematic review analysis, respectively.

Regarding $\mathrm{HCV}$, the prevalence rate in different time zones was estimated in Ethiopia before as 1.9\% [79], $1.3 \%$ [80] and $2.7 \%$ [81] as part of the HCV epidemiological estimation in sub Saharan African countries. However, the above estimates were limited in terms of numbers of studies included, study time, study groups and geographical representation of the studies available throughout the country. For instance, the former two estimates were made from four studies $[9,17,28,56]$ in which two of them were from blood donors of the same study area. However, in the current study, a comprehensive estimate analysis was made from three groups independently analysed as the general population (includes community based, blood donors, healthcare workers, etc.), symptomatic liver disease patients and HIV infected individuals representing a vast geographical area of the country and time. The overall $3.1 \%$ pooled prevalence estimate and the magnitude of anti-HCV antibody from 2.7 to $37.8 \%$ in chronic liver disease patients [44, 49], therefore, might show the true epidemiological picture and the real burden of HCV in Ethiopia. This is also supported by the level of $\mathrm{HCV}$ viraemia reported in $25.4 \%$ of $\mathrm{HCV}$ antibody positive individuals [66]. The pooled prevalence in this study was higher than the recent reports from neighbouring countries of $0.3 \%$ in Djibouti, $0.9 \%$ in Somalia, and $1.0 \%$ in Sudan [82] but in line with a $3.0 \%$ prevalence estimate of most other African countries [79, 83]. The risk factors discussed for transmission of $\mathrm{HBV}$ in Ethiopia also might play their own roles in the transmission of $\mathrm{HCV}$, although the degree of transmission potential varies for both viruses.

Similarly, unlike HBV and $\mathrm{HCV}$, prevalence studies of HAV, HDV and HEV among the general population and liver disease patients were very few in Ethiopia. The data available so far $[47,60,61,84]$ showed a considerate prevalence particularly for HAV and HEV infections. These viruses are transmitted by the faecal-oral route and many of the environmental and socio-economic factors foster the transmission routes. In Ethiopia, the exposure to HAV at least once in every individual was common and the prevalence rates range from eight to $99 \%$ in the general population $[48,85]$. However, unlike the blood born viral hepatitis, HAV and HEV do not commonly exist in a chronic carrier state [84] and they are very different in exposures/transmissions. In Africa, HEV infection is widespread and is expected to be a threat to numerous lives, especially for those pregnant women and their foetuses [4]. A serological data from Egypt showed that the seroprevalence of anti-HEV can reach close to $100 \%$ in the general population [4]; similar to anti-HAV prevalence in Ethiopia and elsewhere in Africa $[84,86]$. It was also reported that in many countries like Sudan, Chad, Uganda, Kenya, Somalia and Ethiopia a number of large HEV outbreaks occurred at different times [4]. For instance, in Uganda alone, the mortality rate among children younger than 2 years of age was $8 \%$ [4]. Similarly, in Ethiopia, the HEV antibody seroprevalence observed in jaundice patients was 93\% [48] but the least from acute sporadic patients (33\%) [48], pregnant women (59\%) and healthy adults (3\%) [48]. According to this report, in the early 1990s, HEV was a common cause of acute sporadic viral hepatitis in Ethiopian patients. In particular, the occurrence during pregnancy was associated with high maternal and foetal morbidity and mortality [48]. Although there is no current study available to compare, the late 1980s HDV reports ranged from 5.8 to $9.6 \%$ could classify Ethiopia as one of an endemic country. The worldwide estimation also indicated that $5 \%$ of HBsAg carriers were infected with HDV [5]. In Ethiopia, an old report showed that the distribution of HBV markers was similar to anti-HDV positive and anti-HDV negative individuals due to the relatively young age of the population and/or hyperendemic condition of the area [60].

Although an increasing pattern of viral hepatitis in general is predictable from HIV infected individuals in Ethiopia, unlike $\mathrm{HCV}$ (5.5\%), the co-prevalence estimate of HBV (5.2\%) with HIV were lower than the estimate of 
other groups. Similarly, the meta-regression analysis showed a decreasing pattern of overall HBsAg prevalence rate over study year. The intensive prevention and control measures done after the era of HIV pandemic might be responsible for HBV exposure reduction. Therefore, this could might encourage a need for integrating HBV management to the HIV prevention and control programs in Ethiopia. However, unlike HBV, the HCV seroprevalence analysis in the HIV infected individuals was higher up to two folds than HIV negative controls. Regarding the HAV, HDV and/or HEV co-infections with HIV in Ethiopia, there are no data available to compare with monoinfection of each hepatitis virus.

\section{Conclusion}

Given the potential limitations arising from small sample size study effects, inconsistency of the screening kits used in the studies as well as study design, time and area heterogeneity, the findings from the systematic review and meta-analysis were in agreement with each other and indicates all forms of viral hepatitis infection are common in Ethiopia. In particular, HBV and HCV and/ or their respective co-infection with HIV are prevalent and endemic. These could be taken as one of the nation's public health problems and potential healthcare threats especially in compromising HIV management. Recent studies on the magnitude of HAV, HDV and HEV are lacking, hence, the need for further studies to generate up-to-date data is recommended. Developing viral hepatitis diagnosis algorithms, treatment schemes and an enhanced HBV vaccination program for children and risk groups in Ethiopia are strongly recommended. The HBV/HCV co-prevalence with HIV supports the need for preventive measures and screening of viral hepatitis in Ethiopia and could be integrated into the country's existing HIV prevention and control programs.

\section{Additional files}

Additional file 1: The major characteristics of studies which reported HBV seroprevalence in Ethiopia. Description of data: Abbreviations; CECentral Ethiopia, NE-North Ethiopia,NW- Northwest Ethiopia, SE-South Ethiopia, SW-Southwest Ethiopia. CS-Cross sectional, RS-Retrospective study, PC-Prospective Cross sectional, PL-Prospective longitudinal study. EIA: Enzyme immunoassay, ELISA: Enzyme linked immunoassay, RIA: Radioimmunoassay, CIA-Chromatographic immunoassay. ANC-antenatal care, MWHs/NMWHs-medical waste handlers / Non-medical waste handlers, CLD-Chronic liver disease. ${ }^{+}$DNA Hybridization. ${ }^{* *}(A=9-12),(B=5-$ 8), $(C=1-4) .{ }^{*}$ For Meta-analysis. Blank cells in the table indicated that the information was unavailable in the original articles. (DOCX $102 \mathrm{~kb}$ )

Additional file 2: The major characteristics of studies which reported HCV seroprevalence in Ethiopia. Description of data: Abbreviations; CECentral Ethiopia, NE-North Ethiopia,NW- Northwest Ethiopia, SE-South Ethiopia, SW-Southwest Ethiopia. CS-Cross sectional, RS-Retrospective study, PC-Prospective Cross sectional, PL-Prospective longitudinal study. EIA: Enzyme immunoassay, ELISA: Enzyme linked immunoassay, RIA: Radioimmunoassay, CIA-Chromatographic immunoassay. ANC-antenatal care, MWHs/NMWHs-medical waste handlers / Non-medical waste handlers, CLD-Chronic liver disease. ${ }^{+}$DNA Hybridization. ${ }^{* *}(A=9-12),(B=5-$ $8),(C=1-4) .{ }^{*}$ For the meta-analysis. Blank cells in the table indicated that the information was unavailable in the original articles. Different quality scores might be observed in a single study which reported both HBV and HCV simultaneously. (DOCX $70 \mathrm{~kb}$ )

Additional file 3: Results of meta-regression analysis of HBV and HCV prevalence. (DOCX $27 \mathrm{~kb}$ )

Additional file 4: Regression plot for mean age and study year to HBV (Fig. A and B) and HCV (Fig. C and D) prevalence. (TIF 625 kb)

Additional file 5: The meta-analysis and forest plot presentation of the HBsAg prevalence in the liver disease patients from 1984 to 2014. (TIF 145 kb)

\section{Abbreviations}

ANC: Antenatal care; Anti-HBCAg: Anti-hepatitis B core antigen; AntiHBeAg: Anti-hepatitis e antigen; Anti-HBs: Anti-hepatitis B surface antigen; Anti-HCV: Anti-hepatitis C virus antibody; ElA: Enzyme immunoassay; ELISA: Enzyme linked immunoassay; HAV: Hepatitis virus; HBeAg: Hepatitis e Ag; HBsAg: Hepatitis B surface antigen; HBV: Hepatitis B virus;

HCC: Hepatocellular carcinoma; HCV: Hepatitis C virus; HDV: Hepatitis D virus; HEV: Hepatitis E virus; HIV: Human immunodeficiency virus; $I^{2}$ : Inconsistency statistics; IQR: Inter quartile range; PRISMA: Preferred Reporting Items for Systematic Reviews and Meta-analysis; RIA: Radioimmunoassay; VCT: HIV voluntary counselling and testing; WHO: World Health Organization

\section{Acknowledgements}

The Authors are grateful for Tewodros Debebe for his valuable suggestions during the manuscript preparation.

\section{Funding}

Received no specific grant to conduct the review.

\section{Availability of data and material}

The data generated and/or analysed during this study are included as the additional files in this publication.

\section{Authors' contributions}

YB: Conceived and designed the review, performed data extraction, carried out the analysis and interpretation of the data, and drafting the manuscript. MM, AM, UGL: Conception, conducted the quality assessment, data interpretation and revising the manuscript. ED: Data interpretation and revising the manuscript. All the authors have read and approved the final version of the manuscript.

\section{Competing interests}

The authors declare that they have no competing interests.

\section{Consent for publication}

Not applicable.

\section{Ethics approval and consent to participate}

Not applicable.

\section{Author details}

${ }^{1}$ Institute of Virology, Faculty of Medicine, Leipzig University, Leipzig, Germany. ${ }^{2}$ School of Biomedical and Laboratory Sciences, College of Medicine and Health Sciences, University of Gondar, Gondar, Ethiopia. ${ }^{3}$ Department of Internal Medicine, College of Medicine and Health Sciences, University of Gondar, Gondar, Ethiopia.

Received: 23 July 2016 Accepted: 3 December 2016

Published online: 19 December 2016

\section{References}

1. WHO. Global policy report on the prevention and control of viral hepatitis. WC: WHO member states; 2013. p. 536.

2. Hwang EW, Cheung R. Global epidemiology of hepatitis B virus (HBV) infection. N Am J Med Sci. 2011;4:7-13. 
3. Jacobsen $\mathrm{KH}$, Wiersma ST. Hepatitis A virus seroprevalence by age and world region, 1990 and 2005. Vaccine. 2010;28(41):6653-7.

4. Kim J, Nelson KE, Panzner U, et al. A systematic review of the epidemiology of hepatitis E virus in Africa. BMC Infect Dis. 2014;14:308.

5. Alves C, Branco C, Cunha C. Hepatitis Delta Virus: A Peculiar Virus. Adv Virol. 2013;2013(3):1-11.

6. Tsega E. Current views on liver diseases in Ethiopia. Ethiop Med J. 1977; 15(2):75-82.

7. Bane A, Patil A, Khatib M. Healthcare cost and access to care for viral hepatitis in Ethiopia. IJIAS. 2014;9(4):1718-23.

8. Dessie A, Abera B, Wale F. Seroprevalence of major blood-borne infections among blood donors at Felege Hiwot referral hospital, Northwest Ethiopia. EJHD. 2007;21(1):68-9.

9. Diro E, Alemu S. G/Yohannes A. Blood safety \& prevalence of transfussion transmissible viral infections among donors at the Red Cross Blood Bank in Gondar University Hospital. Ethiop Med J. 2008;46(1):7-13.

10. Mazengia A, Yismaw G, Anagaw B, Unakal C. Seroprevalence and associated risk factors of HBV and HCV among people attending the HIV VCT centre at Deber Markos Referral Hospital, Northwest Ethiopia. J Pharm Biomed Sci. 2013;30:22.

11. Alemayehu A, Tassachew $Y$, Sisay $Z$, et al. Prevalence and risk factors of Hepatitis $C$ among individuals presenting to HIV testing centers, Hawassa city, Southern Ethiopia. BMC Res Notes. 2011;4:193.

12. Hadush H, Gebre-Selassie S, Mihret A. Hepatitis C virus and human immunodeficiency virus coinfection among attendants of voluntary counseling and testing centre and HIV follow up clinics in Mekelle Hospital. Pan Afr Med J. 2013;14:107.

13. Assefa A, Mathewos B, Alemu A, et al. Hepatitis B and C viral infections among blood donors at Bahir Dar, Ethiopia. IJMRHS. 2013;2(3):624-30.

14. Huruy K, Kassu A, Mulu A, et al. Seroprevalence and Risk Factors for Hepatitis B Virus Infection in the Healthy Blood Donors at Jimma University Hospital, Southwest Ethiopia. Pharmacologyonline. 2008:3:32-7.

15. Yami A, Alemseged F, Hassen A. Hepatitis B and C Viruses Infections and Their Association with Human Immunodeficiency Virus: A Cross-Sectional Study among Blood Donors in Ethiopia. Ethiop J Health Sci. 2011;21(1):67-75.

16. Rahlenbeck SI, Yohannes G, Molla K, et al. Infection with HIV, syphilis and hepatitis B in Ethiopia: a survey in blood donors. Int J STD AIDS. 1997:8(4):261-4.

17. Tessema B, Yismaw G, Kassu A, et al. Seroprevalence of HIV, HBV, HCV and syphilis infections among blood donors at Gondar University Teaching Hospital, Northwest Ethiopia: declining trends over a period of five years BMC Infect Dis. 2010;10:111.

18. Harvard Initiative for Global Health, Institute for Health metrics and evaluation at the University of Washington, Johns Hopkins University, University of Queensland, World Health Organization. The global burden of diseases, injuries, and risk factors study operations manual final draft. 2008.

19. Moher D. Preferred Reporting Items for Systematic Reviews and Meta-Analyses: The PRISMA Statement. Ann Intern Med. 2009;151(4):264.

20. Downs SH, Black N. The feasibility of creating a checklist for the assessment of the methodological quality both of randomised and non-randomized studies of health care interventions. J Epidemiol Community Health. 1998;52:377-84.

21. DerSimonian R, Laird N. Meta-analysis in clinical trials. Control Clin Trials. 1986;7(3):177-88.

22. Higgins P T J. Commentary: Heterogeneity in meta-analysis should be expected and appropriately quantified. Int J Epidemiol. 2008;37(5):1158-60.

23. UN World population prospects. Available at http://esa.un.org/wpp/unpp/ p2k0data.asp. Accessed 10 July 2015.

24. Frame JD. Hepatitis among missionaries in Ethiopia and Sudan. Susceptible at high risk. JAMA. 1968;203(10):819-26.

25. Kefene H, Rapicetta M, Rossi GB, et al. Ethiopian National Hepatitis B Study. J Med Virol. 1988;24(1):75-84.

26. Rapicetta M, Hailù K, Morace G, et al. Prevalence of HBeAg, anti-HBe serological markers and HBV-DNA in asymptomatic carriers in Ethiopia. Eur J Epidemiol. 1989;5(4):481-5.

27. Abebe A, Nokes DJ, Dejene A, et al. Seroepidemiology of hepatitis B virus in Addis Ababa, Ethiopia: transmission patterns and vaccine control. Epidemiol Infect. 2003;131(1):757-70.

28. Berhe N, Myrvang B, Gundersen SG. Intensity of Schistosoma mansoni, hepatitis B, age, and sex predict levels of hepatic periportal thickening/ fibrosis (PPT/F): a large-scale community-based study in Ethiopia. Am J Trop Med Hyg. 2007;77(6):1079-86.
29. Kefenie H, Desta B, Abebe A, et al. Prevalence of hepatitis B infection among hospital personnel in Addis Ababa (Ethiopia). Eur J Epidemiol. 1989; 5(4):462-7.

30. Geberemicheal A, Gelaw G, Moges F, Dagnew M. Seroprevalence of hepatitis B virus infections among health care workers at the Bulle Hora Woreda Governmental Health Institutions, Southern Oromia, Ethiopia. J Environ Occup Sci. 2013;2(1):9-14

31. Shiferaw $Y$, Abebe $T$, Mihret A. Hepatitis B virus infection among medical waste handlers in Addis Ababa, Ethiopia. BMC Res Notes. 2011;4:479.

32. Anagaw B, Shiferaw $Y$, Anagaw $B$, et al. Seroprevalence of hepatitis B and C viruses among medical waste handlers at Gondar town Health institutions, Northwest Ethiopia. BMC Res Notes. 2012;5:55.

33. Ramos JM, Belda S, Reyes F, et al. Prevalence of HIV, HBV, HCV, HTLV and Treponema pallidum among patients attending a rural hospital in Southern Ethiopia. J Clin Virol. 2012;53(3):268-9.

34. Erena AN, Tefera TB. Prevalence of hepatitis B surface antigen ( $\mathrm{HBsAg})$ and its risk factors among individuals visiting Goba General Hospital, South East Ethiopia, 2012. BMC Res Notes. 2014;7:833.

35. Moges F, Kebede Y, Kassu A, et al. Seroprevalence of HIV, hepatitis B infections and syphilis among street dwellers in Gondar city, Northwest Ethiopia. EJHD. 2006;20:3.

36. Tegegne D, Desta K, Tegbaru B, et al. Seroprevalence and transmission of Hepatitis B virus among delivering women and their new born in selected health facilities, Addis Ababa, Ethiopia: a cross sectional study. BMC Res Notes. 2014;7:239.

37. Zenebe $Y$, Mulu W, Yimer M, et al. Sero-prevalence and risk factors of hepatitis $B$ virus and human immunodeficiency virus infection among pregnant women in Bahir Dar city, Northwest Ethiopia: a cross sectional study. BMC Infect Dis. 2014;14:118.

38. Walle F, Asrat D, Alem A, Tadesse E, Desta K. Prevalence of Hepatitis B Surface Antigen among Pregnant Women Attending Antenatal Care Service at DebreTabor Hospital, Northwest Ethiopia. Ethiopia J Health Sci. 2008;17(1):13-21.

39. Tiruneh M. Seroprevalence of multiple sexually transmitted infections among antenatal clinic attendees in Gondar Health Center, northwest Ethiopia. Ethiop Med J. 2008:46(4):359-66.

40. Awole M, Gebre-Selassie S. Seroprevalence of HBsAg and its risk factors among pregnant women in Jimma, Southwest Ethiopia. EJHD. 2005; 19(1):45-50.

41. Mekonnen D, Gebre-Selassie S, Fantaw S, et al. Prevalence of hepatitis B virus in patients with diabetes mellitus: a comparative cross sectional study at Woldiya General Hospital, Ethiopia. Pan Afr Med J. 2014;17:40.

42. Shimelis T, Torben W, Medhin G, et al. Hepatitis B virus infection among people attending the voluntary counselling and testing centre and antiretroviral therapy clinic of St Paul's General Specialised Hospital, Addis Ababa, Ethiopia. Sex Transm Infect. 2008;84(1):37-41.

43. Bugssa G, Dessalegn B, Dimtsu B, Berhane Y. Prevalence and factors associated with HIV and hepatitis B virus infections among female commercial sex workers in Mekelle, Ethiopia: cross sectional study. IJPSR. 2015;6(1):135-46.

44. Ayele AG, Gebre-Selassie S. Prevalence and Risk Factors of Hepatitis B and Hepatitis C Virus Infections among Patients with Chronic Liver Diseases in Public Hospitals in Addis Ababa. Ethiopia: ISRN Tropical Medicine; 2012. 2013(ID 563821).

45. Gebreselassie L. Spectrum of hepatitis B virus infection in Ethiopia. IARC Sci Publ. 1984;63:213-20.

46. Tsega E, Nordenfelt E, Hansson BG, et al. Chronic liver disease in Ethiopia: a clinical study with emphasis on identifying common causes. Ethiop Med J. 1992;30(2 Suppl):1-33.

47. Tsega E, Krawczynski K, Hansson BG, et al. Outbreak of acute hepatitis E virus infection among military personnel in northern Ethiopia. J Med Virol. 1991;34(4):232-6.

48. Tsega E, Hansson BG, Krawczynski K, et al. Acute sporadic viral hepatitis in Ethiopia: causes, risk factors, and effects on pregnancy. Clin Infect Dis. 1992; 14(4):961-5

49. Tsega $E$, Nordenfelt $E$, Hansson BG. Hepatitis C virus infection and chronic liver disease in Ethiopia where hepatitis B infection is hyperendemic. Trans R Soc Trop Med Hyg. 1995:89(2):171-4.

50. Tesfa H, Biadgo B, Getachew F, et al. Seroprevalence of hepatitis B and C virus infection among patients attending serology laboratory of Gondar University Hospital. BMC Res Notes. 2013;6:164. 
51. Taye S, Abdulkerim A, Hussen M. Prevalence of hepatitis B and C virus infections among patients with chronic hepatitis at Bereka Medica Center, Southeast Ethiopia: a retrospective study. BMC Res Notes. 2014;7:272.

52. Tsega $E$, Tsega M, Mengesha B, et al. Transmission of hepatitis B virus infection in Ethiopia with emphasis on the importance of vertical transmission. Int J Epidemiol. 1988;17(4):874-9.

53. Manyazewal T, Sisay Z, Biadgilign S, et al. Hepatitis B and hepatitis $C$ virus infections among antiretroviral-naive and -experienced HIV co-infected adults. J Med Microbiol. 2014;63(5):742-7.

54. Flatau E, Segol O, Shneour A, et al. Prevalence of markers of infection with hepatitis B and C viruses in immigrants of operation Solomon, 1991. Isr J Med Sci. 1992;29(6-7):387-9.

55. Ayele W, Nokes DJ, Abebe A, et al. Higher prevalence of anti-HCV antibodies among HIV-positive compared to HIV-negative inhabitants of Addis Ababa, Ethiopia. J Med Virol. 2002;68(1):12-7.

56. Frommel $\mathrm{D}$, Tekle-Haimanot $\mathrm{R}$, Berhe $\mathrm{N}$, et al. A survey of antibodies to hepatitis C virus in Ethiopia. Am J Trop Med Hyg. 1993;49(4):435-9.

57. Gelaw B, Mengitsu Y. The prevalence of HBV, HCV and malaria parasites among blood donor in Amhara and Tigray regional states. EJHD. 2008; 22(1):3-7.

58. Ali S, Abera S, Mihret A, et al. Association of Hepatitis C Virus Infection with Type II Diabetes in Ethiopia: A Hospital-Based Case-control Study. Interdiscip Perspect Infect Dis. 2012;2012:354656.

59. Tsega E, Mengesha B, Hansson BG, et al. Hepatitis A, B, and delta infection in Ethiopia: a serologic survey with demographic data. Am J Epidemiol. 1986;123(2):344-51.

60. Rapicetta M, Hailu K, Ponzetto A, et al. Delta hepatitis virus infection in Ethiopia. Eur J Epidemiol. 1988;4(2):185-8.

61. Tsega E, Krawczynski K, Hansson BG, et al. Hepatitis E virus infection in pregnancy in Ethiopia. Ethiop Med J. 1993;31(3):173-81.

62. Negero A, Sisay Z, Medhin G. Prevalence of Hepatitis B surface antigen (HBsAg) among visitors of Shashemene General Hospital voluntary counseling and testing center. BMC Res Notes. 2011:4:35.

63. Berhe H, Yismaw G, Addis Z. H/slassie H, Anagaw B, Unakal C. Seroprevalence and Associated Risk Factors of Human Immunodeficiency Virus and Hepatitis B Virus Infections among Prison Inmates. J Pharm Biomed Sci. 2013;30(23):1035-45.

64. Wondimeneh Y, Alem M, Asfaw F, et al. HBV and HCV seroprevalence and their correlation with CD4 cells and liver enzymes among HIV positive individuals at University of Gondar Teaching Hospital, Northwest Ethiopia. Virol J. 2013;10:171.

65. Belayneh F. Prevalence of Hepatitis B Virus Infection and Associated Factors among HIV Positive Adults Attending ART Clinic at Hawassa Referral Hospital, SNNPR, Ethiopia. OALib. 2015;02(05):1-7.

66. Abreha T, Woldeamanuel Y, Pietsch C, et al. Genotypes and viral load of hepatitis $C$ virus among persons attending a voluntary counseling and testing center in Ethiopia. J Med Virol. 2011;83(5):776-82.

67. Balew M, Moges F, Yismaw G, Unakal C. Assessment of hepatitis B virus and hepatitis $C$ virus infections and associated risk factors in HIV infected patients at Debretabor hospital, South Gondar, Northwest Ethiopia. Asian Pac J Trop Dis. 2014;4(1):1-7.

68. Taye S, Lakew M. Impact of hepatitis C virus co-infection on HIV patientsbefore and after highly active antiretroviral therapy: an immunological and clinical chemistry observation, Addis Ababa, Ethiopia. BMC Immunol. 2013;14:23.

69. Abera B, Zenebe $Y$, Mulu W, et al. Seroprevalence of hepatitis B and C viruses and risk factors in HIV infected children at the Felgehiwot referral hospital, Ethiopia. BMC Res Notes. 2014;7:838.

70. Musa BM, Bussell S, Borodo MM, et al. Prevalence of hepatitis B virus infection in Nigeria, 2000-2013: a systematic review and meta-analysis. Niger J Clin Pract. 2015;18(2):163-72.

71. Jayaraman $S$, Chalabi Z, Perel $P$, et al. The risk of transfusion-transmitted infections in sub-Saharan Africa. Transfusion. 2010;50(2):433-42.

72. Mbanya DN, Takam D, Ndumbe PM. Serological findings amongst first-time blood donors in Yaoundé, Cameroon: is safe donation a reality or a myth? Transfus Med. 2003;13(5):267-73.

73. Myers-JDC-Brookdale Institute The Ethiopian-Israeli Community: Facts and Figures. http://brookdale.jdc.org.il/_Uploads/dbsAttachedFiles/The-EthiopianIsraeli-Community-Facts-and-Figures-full-report-February-2012.pdf. Accessed 10 July 2015.
74. Chemtov D, Rosen $H$, Shtarkshall $R$, et al. A culturally specific educational program to reduce the risk of HIV and HBV transmission among Ethiopian immigrants to Israel: a preliminary report on training veteran immigrants as health educators. Isr J Med Sci. 1993;29(6-7):437-42.

75. Richard MH. Cross-cultural Medicine and Diverse Health Beliefs Ethiopians Abroad. West J Med. 1997;166(1):29-36.

76. Abeje G, Azage M. Hepatitis B vaccine knowledge and vaccination status among health care workers of Bahir Dar City Administration, Northwest Ethiopia: a cross sectional study. BMC Infect Dis. 2015;15:30.

77. Bekele A, Tadesse A. Status of hepatitis B vaccination among surgeons practicing in Ethiopia: a cross sectional study. Ethiop Med J. 2014;52(3): 107-12.

78. Tsega E. Hepatocellular carcinoma in Ethiopia. A prospective clinical study of 100 patients. East Afr Med J. 1977;54(5):281-92.

79. Madhava V, Burgess C, Drucker E. Epidemiology of chronic hepatitis C virus infection in sub-Saharan Africa. Lancet Infect Dis. 2002;2(5):293-302.

80. Gower E, Estes C, Blach S, et al. Global epidemiology and genotype distribution of the hepatitis C virus infection. J Hepatol. 2014;61(1 Suppl): S45-57.

81. Riou J, Aït Ahmed M, Blake A, et al. Hepatitis C virus seroprevalence in adults in Africa: a systematic review and meta-analysis. J Viral Hepat. 2016; 23(4):244-55.

82. Chaabna K, Kouyoumjian SP, Abu-Raddad LJ. Hepatitis C Virus Epidemiologyin Djibouti, Somalia, Sudan, and Yemen: Systematic Review and Meta-Analysis. PLoS One. 2016;11(2):e0149966.

83. Karoney MJ, Siika AM. Hepatitis C virus (HCV) infection in Africa: a review. Pan Afr Med J. 2013;14:1.

84. Tsega E, Nordenfelt E, Mengesha B, et al. Age-specific prevalence of hepatitis A virus antibody in Ethiopian children. Scand J Infect Dis. 1990; 22(2):145-8

85. Gebreselassie L. Prevalence of specific markers of viral hepatitis A and B among an Ethiopian population. Bull World Health Organ. 1983;61(6):991-6.

86. Stoszek SK, Engle RE, Abdel-Hamid M, et al. Hepatitis E antibody seroconversion without disease in highly endemic rural Egyptian communities. Trans R Soc Trop Med Hyg. 2006;100(2):89-94.

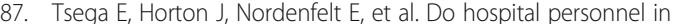
hyperendemic areas require immunization against hepatitis B virus (HBV) infection? Is vertical transmission of HBV infection common in this group? Ethiop Med J. 1989;27(3):101-6.

88. Enqueselassie F, Dejene A, Messele T, et al. Seroepidemiological study of Hepatitis B virus in Addis Ababa, Ethiopia. J Clin Epidemiol. 1997:50:S15.

89. Tsega E, Mengesha B, Nordenfelt E, et al. Prevalence of hepatitis B virus markers among Ethiopian blood donors: is HBsAg screening necessary? Trop Geogr Med. 1987;39(4):336-40.

90. Zawde D, Sisay Y. National blood requirement, serum ALT and hepatitis in Ethiopian blood donors. Ethiop Med J. 1991;29(4):175-83.

91. Ben-Porath E, Hornstein L, Zeldis J, et al. Hepatitis B virus infection and liver disease in Ethiopian immigrants to Israel. Hepatology. 1986;6(4):662-6.

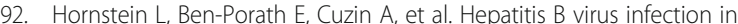
Ethiopian immigrants to Israel. Isr J Med Sci. 1991;27(5):268-72.

93. Chemtob D, Fassberg J, Kalka I, et al. Prevention strategy of hepatitis B virus infection among the Ethiopian community in Israel. Isr J Med Sci. 1991;27(5): 273-7.

94. Alkan ML, Maayan S, Belmaker I, et al. Serological markers for hepatitis B and treponemal infection among HIV carriers from Ethiopia. Isr J Med Sci. 1993;29(6-7):390-2.

95. Bisharat N, Elias M, Raz R, et al. Familial pattern of infection with hepatitis B virus among immigrating Ethiopian Jews in Israel. Eur J Epidemiol. 1998; 14(1):89-91.

96. Zamir C, Dagan R, Zamir D, et al. Evaluation of screening for hepatitis B surface antigen during pregnancy in a population with a high prevalence of hepatitis B surface antigen-positive/hepatitis B e antigen-negative carriers. Pediatr Infect Dis J. 1999;18(3):262-6.

97. Bezabeh YH, Muluneh DM, Gebere Sillassie S, Kloos H. Higher prevalence of Hepatitis B virus Infection among ARV- exposed than naive HIV-infected individuals in North Shewa Zone, Ethiopia. J HIV ADIS Res. 2015;71(1):10-7

98. Molla S, Munshea A, Nibret E. Seroprevalence of hepatitis B surface antigen and anti HCV antibody and its associated risk factors among pregnant women attending maternity ward of Felege Hiwot Referral Hospital, northwest Ethiopia: a cross-sectional study. Virol J. 2015;12:204. 
99. Birku T, Gelaw B, Moges F, Assefa A. Prevalence of hepatitis B and C viruses infection among military personnel at Bahir Dar Armed Forces General Hospital, Ethiopia. BMC Res Notes. 2015;8:737.

100. Mulu W, Gidey B, Chernet A, et al. Hepatotoxicity and associated risk factors in HIV-infected patients receiving antiretroviral therapy at Felege Hiwot Referral Hospital, Bahirdar, Ethiopia. Ethiop J Health Sci. 2013;23(3):217-26.

Submit your next manuscript to BioMed Central and we will help you at every step:

- We accept pre-submission inquiries

- Our selector tool helps you to find the most relevant journal

- We provide round the clock customer support

- Convenient online submission

- Thorough peer review

- Inclusion in PubMed and all major indexing services

- Maximum visibility for your research

Submit your manuscript at www.biomedcentral.com/submit 